\title{
Marketing and Poverty Alleviation: The Perspective of the Poor
}

Aneel Karnani

University of Michigan

Follow this and additional works at: https://digitalcommons.uri.edu/mgdr

Part of the Anthropology Commons, Economics Commons, Marketing Commons, Other Business Commons, Public Affairs, Public Policy and Public Administration Commons, and the Sociology Commons

\section{Recommended Citation}

Karnani, Aneel (2017) "Marketing and Poverty Alleviation: The Perspective of the Poor," Markets, Globalization \& Development Review. Vol. 2: No. 1, Article 5.

DOI: 10.23860/MGDR-2017-02-01-05

Available at: https://digitalcommons.uri.edu/mgdr/vol2/iss1/5

This Dialogue is brought to you for free and open access by DigitalCommons@URI. It has been accepted for inclusion in Markets, Globalization \& Development Review by an authorized editor of DigitalCommons@URI. For more information, please contact digitalcommons-group@uri.edu. 
Marketing and Poverty Alleviation: The Perspective of the Poor

\section{Markets, Globalization \& Development Review}
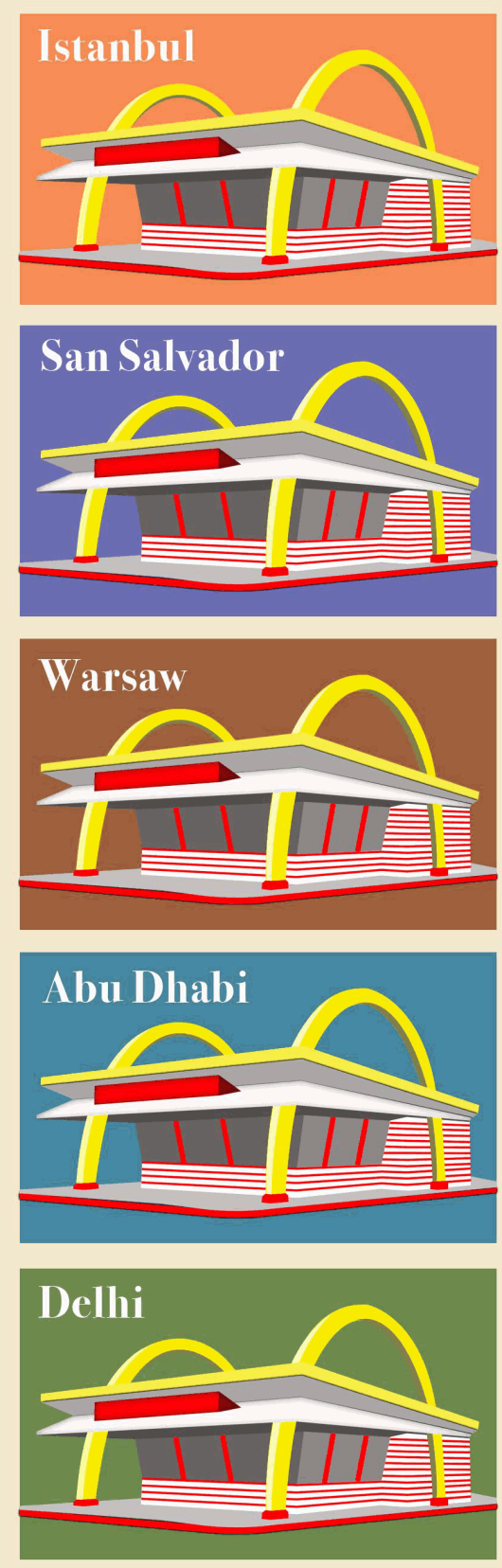
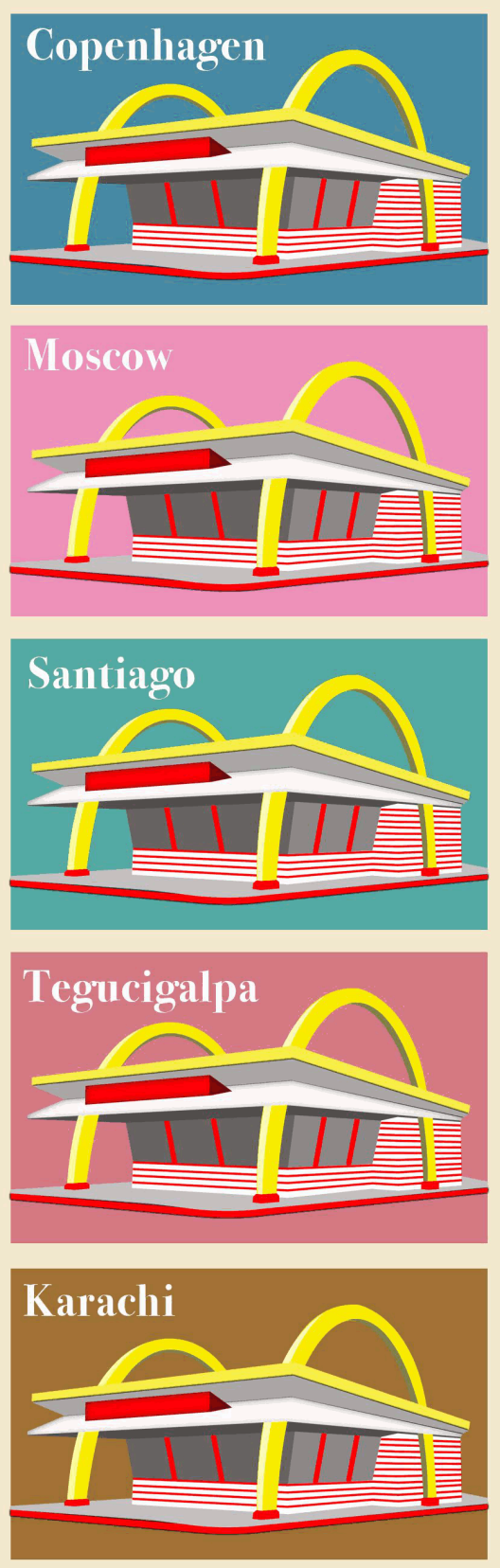
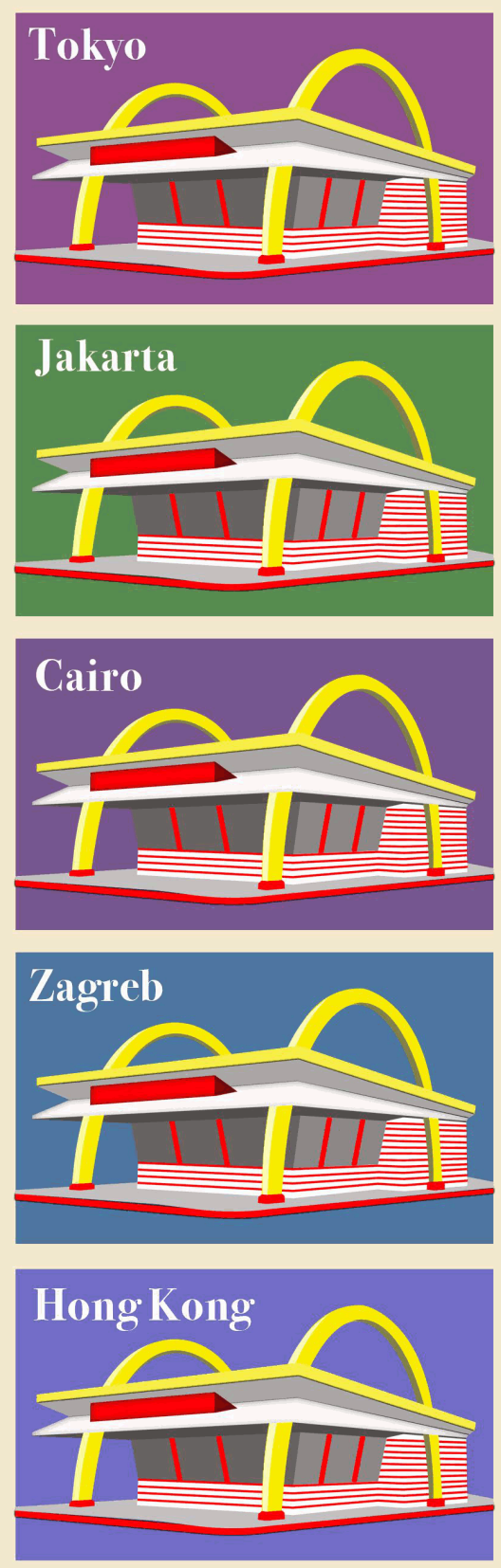

This dialogue is available in Markets, Globalization \& Development Review: https://digitalcommons.uri.edu/mgdr/ 


\section{Marketing and Poverty Alleviation: The Perspective of the Poor}

Widespread poverty is an economic, social, political and moral problem. For about 70 years, various institutions have tried to address this challenge: local governments, developed country governments, international organizations (such as the World Bank and the United Nations), aid foundations and non-governmental organizations. So far, the intellectual discourse has been largely in the fields of public policy and development economics. From the 1980s, management experts and business school academics have entered this arena. Two events precipitated this movement: microfinance was pioneered by Muhammad Yunus in Bangladesh in the 1980s and grew rapidly in the 1990s, and the research on 'base/bottom of the pyramid' (BOP) strategies was initiated by the late CK Prahalad and his co-authors in 1999. Both these marketoriented approaches promised win-win solutions: reduce poverty while simultaneously making a profit. This is, of course, a very appealing proposition and has drawn much attention from senior executives, large companies, and business school academics. Kolk et al. (2014) in their review of research on the BOP concept identified 104 articles published in journals during 2000-2009; this count excluded books, chapters and case studies. There are even a few critical views of BOP approaches, from business school scholars (see, for example, Boje and Hillon 2017, in this journal issue).

In the introductory issue of this journal, Achrol and Kotler (2016), two business school professors, joined this movement and offered "a window on some developing ideas coming from marketing". Achrol and Kotler (2016) assert that the microfinance model has been a success, and their judgment on the BOP approach "lies somewhere between Prahalad's enthusiasm and Karnani's cynicism". They discuss how their 'social marketing' model can be used to address the needs of the poor, and conclude that the marketing model can be "applied to raising the consumption capacity and quality of life of the world's 4 billion consumers in the BOP".

In this article, I will argue that both the microfinance model and the BOP proposition have not delivered on their promise to help reduce poverty. Both these approaches are conceptually flawed and empirically weak, and recently have been losing the support of both researchers and practitioners. The best way to reduce poverty is to focus on raising the productive capacity - not the consumption capacity - of the poor. This 
implies poverty reduction efforts must focus on two dimensions: raising income of the poor, and providing the poor access to public services (such as public health, education, sanitation, infrastructure and security). First, the best way to raise income is to create employment opportunities for the poor. The private sector is clearly the best engine for job creation; the government can play a useful facilitating role. Second, governments are responsible for, and should be held accountable for providing basic public services. Social marketing can play a useful role in designing and delivering these services to the poor more effectively.

\section{Defining Poverty}

Nobel Prize-winning economist Amartya Sen (2000) has eloquently argued that development can be seen as a "process of expanding the real freedoms that people enjoy." Conversely, poverty is the lack of those freedoms, and is a multifaceted phenomenon. Nonetheless, it is easy to argue that income is very important, perhaps the single most important, measure of poverty. Poverty is therefore most often measured in monetary terms and defined as consumption below a certain benchmark. There is no objective benchmark, and measures of poverty necessarily entail subjective judgment. To have a sensible discussion about poverty it is necessary to first agree on a definition of poverty. It is difficult, and probably impossible, to prescribe solutions without first defining the nature and scope of the problem.

There is much confusion in the BOP field about where to draw the poverty line (for a recent discussion, see (Yurdakul, Atik and Dholakia 2017); and, unfortunately, Achrol and Kotler (2016) fall into the same trap. Prahalad and Hart (2002) in their first article on this subject, defined poverty as an annual per capita income below $\$ 1,500$ at purchasing power parity (PPP). Later in 2002, Prahalad and Hammond (2002) set the poverty line at $\$ 2,000$ PPP per year. In his 2005 book, Prahalad (2005) uses $\$ 2 /$ day poverty standard, equivalent to $\$ 730$ per year. The Next 4 Billion report, published in 2007 by the International Finance Corporation, defines the poor as those with annual incomes below $\$ 3,000$ PPP. There is no discussion at all in the BOP literature of how to choose the income level for defining the poor.

In most countries, the government determines its own national poverty line. Since 1990, the World Bank has measured poverty by the standards commonly used in low-income countries, which generated the widely accepted 'dollar a day' poverty line. People below the 'extreme poverty' line of ' $\$ 1$ per day' cannot meet basic needs for survival: nutrition, health care, safe drinking water, sanitation, education for children, 
adequate shelter and clothing. This poverty line is then converted to local currency using the latest Purchasing Power Parity or PPP exchange rates, and the local consumer price indices are then used to adjust for inflation. This work was updated recently resulting in a poverty line of $\$ 1.90$ per day in 2011 PPP prices, still often referred to as ' $\$ 1$ per day' poverty line. This definition of 'extreme poverty' is probably too conservative. Another commonly used standard, more representative of middle-income countries, is '\$2 per day,' equivalent to $\$ 3.10$ in 2011 PPP prices. At this level of 'moderate poverty,' the basic needs of survival are met, but just barely.

Both these measures of poverty are widely used in development economics and public policy fields. For example, in 2002 all the 191 United Nations member states agreed to the Millennium Development Goals. The first goal of this declaration is to eradicate extreme poverty and hunger, and set the target: "Halve, between 1990 and 2015, the proportion of people whose income is less than $\$ 1$ a day" (United Nations 2015). The World Bank uses both $\$ 1 /$ day and $\$ 2 /$ day poverty lines. In his book on BOP, Prahalad (2005) uses the $\$ 2$ per day criterion; I too shall use the $\$ 2 /$ day poverty line (\$3.10 in 2011 prices) in this paper.

Achrol and Kotler (2016) mention the World Bank's $\$ 1.90$ poverty line and also mention the US standard of poverty of $\$ 10$ per day, and take no clear position on this very wide range. Later, they call the $\$ 3,000$ PPP measure used by the International Finance Corporation "rather liberal" never mind that it is less liberal than their earlier mention of the US $\$ 10 /$ day poverty line.

Defining the poor using a poverty line ranging from $\$ 2 /$ day to $\$ 10 /$ day is much too ambiguous. That is a big difference. To an affluent researcher, a person living on $\$ 10$ /day seems very poor, but to a person living on $\$ 2 /$ day, an income of $\$ 10 /$ day is a dramatic improvement. All research in development economics uses a poverty line at or below $\$ 2 /$ day (\$3.10 in 2011 prices). Setting the poverty line too high in effect marginalizes those usually considered poor. If the poor and non-poor are combined in a single poverty reduction program, the non-poor will always drive out the poor. Muhammad Yunus (1998) has argued for a "strict definition of who the poor are - there is no room for conceptual vagueness".

\section{Number of Poor People}

Having chosen a poverty line, the next step is to estimate the number of people below the poverty line. Prahalad and Hart (2002) state that there are 4 billion people with per capita income below $\$ 1,500$ per year. 
Prahalad and Hammond (2002) assert there are 4 billion people with per capita income below $\$ 2,000$ per year. Prahalad $(2005$, p.4) states that there are 4 billion people with per capita income below $\$ 2$ per day. The Next 4 Billion report also estimated the BOP population to be 4 billion even though it used the poverty line of $\$ 3,000$ per year (IFC, 2007). There must be something magical about the number 4 billion! Achrol and Kotler also mention the "world's 4 billion consumers in the BOP". So, what are the true facts?

According to the World Bank, 10.7 percent of the world's population, or about 767 million people, lived on less than \$1.90 PPP per day in 2013. If we use the World Bank's \$3.10 PPP per day standard, 26.9 percent of the world's population, or about 1.9 billion people, are poor - all significantly less than '4 billion.' This is not to minimize the problem of poverty; by any measure, the prevalence of poverty is a crisis. Precision is not critical, but getting the order of magnitude right is necessary for understanding the nature of the problem and the size of the market opportunity.

The BOP argument as well as Achrol and Kotler (2016) often confuse the emerging middle class in developing countries for the poor. The Next 4 Billion (IFC 2007) report claims that 98.6 percent of the population of India is in the base of the pyramid! According to this report, in most developing countries, at least 95 percent of the population falls below the poverty line. Indeed, economist Warnholz (2007) remarks, "Seen in this light, the BOP argument could simply be restated as a call for big business to sell their products in low and middle-income countries. This is neither a novel nor a particularly provocative idea". This confusion could explain why Achrol and Kotler (2016) mention the Tata Nano car as an example, even though they realize that the poor cannot possibly afford any car. Such confusing the middle class for the poor probably prompted BOP critic Anand Jaiswal (2008) to title his article "The Fortune at the Bottom or the Middle of the Pyramid".

\section{BOP Proposition}

The BOP proposition (Prahalad 2005) argues that private companies, in particular large multinational companies, can make significant profits by selling to the poor, and simultaneously bring prosperity to the poor. This is, of course, a very appealing proposition and has attracted much attention. The BOP proposition is indeed too good to be true. It is seductively appealing, but it is riddled with fallacies. There is little glory or fortune at the bottom of the pyramid - unfortunately, it is (almost) all a mirage; I have argued elsewhere that the BOP proposition is both logically flawed and 
inconsistent with the evidence (Karnani 2007; Karnani 2011). More recently there has been much research refuting the BOP proposition (for example, Jaiswal 2008; Gupta 2013). Even Stuart Hart, one of the original researchers of the BOP proposition, has recently conceded, "the unfortunate truth is that most BOP ventures and corporate initiatives over the past decade have either failed outright, or achieved only modest success at great cost" (Hart 2015).

The BOP proposition emphasizes the opportunity for significant corporate profits, and yet, in a search for empirical support, proponents often cite examples of not-for-profit organizations. After an extensive survey of market-based solutions to reducing poverty, the consulting firm Monitor Group (2009) concluded that "only a small handful - mostly wellpublicized ones like Grameen Bank and Aravind Eye Care - attained a scale sufficient to transform a 'business model' into a 'solution'". It is ironic, and instructive, that both are not-for-profit organizations, and thus cannot be classified as profitable businesses.

Achrol and Kotler (2016) are appropriately critical of the BOP proposition. In particular, they are concerned that the "profit motive tends to get primacy in the BOP potential as described by Prahalad and his colleagues." In fact, Prahalad (2005) explicitly states that BOP markets "cannot merely be relegated to the realm of corporate social responsibility (CSR) initiatives". Prahalad argues that BOP markets must become integral to the success of the firm - that is, be profitable - in order to "command senior management attention and sustained resource allocation".

Governments and civil society (including not-for-profits, NGOs, charity organizations, and religious organizations) have, for long, helped reduce poverty through a variety of programs. What makes the BOP proposition so novel and so appealing is, of course, the primacy of the profit motive. Having rejected the central tenet of the BOP proposition, it is inconsistent how Achrol and Kotler (2016) conclude that their position on the BOP proposition "lies somewhere between Prahalad's enthusiasm and Karnani's cynicism". They advocate social marketing whose goal, by definition, is "achieving a socially desirable outcome. ... The social marketing approach to poverty differs from the BOP model in that profit is neither a primary nor a necessary condition for it". The logical conclusion from this is that social marketing cannot be reconciled with the BOP proposition. 


\section{Microfinance}

\section{The Rise of Microfinance}

The Nobel Peace Price for 2006 was awarded to the Grameen Bank in Bangladesh and its founder Muhammad Yunus, a pioneer of the microcredit movement. Dr. Yunus started experimenting with forms of microfinance in the late 1970s and then founded the iconic Grameen Bank in 1983. In thirty years microcredit had gone from an experiment to the newest silver bullet for reducing poverty. The central objective of the Grameen Bank has been to "reverse the age-old vicious circle of "low income, low saving \& low investment', into virtuous circle of 'low income, injection of credit, investment, more income, more savings, more investment, more income"'.

As microcredit programs became increasingly focused on growing the size of their loan portfolios, they outgrew their charitable roots and looked for new sources of capital to expand their reach. With encouragement from philanthropists, many turned to commercial equity investors. This was congruent also with the growing view at that time that the private sector could profitably play a larger role in poverty reduction. Global commercial banks, such as Deutsche Bank AG and Citigroup Inc., established microcredit funds. Elisabeth Rhyne, who ran the Center for Financial Inclusion, said in Congressional testimony in 2010 that banks and finance firms served 60 percent of all microcredit clients. In India 95 percent of all micro credit borrowers are covered by for-profit microfinance institutions (M-CRIL 2012).

Since private equity capital is incompatible with the nonprofit approach, sometime around 2005 many nonprofit microcredit organizations changed their status to for-profit enterprises. One of the most prominent examples of this trend was Banco Compartamos in Mexico, which in 2007 launched an initial public stock offering that brought in $\$ 458$ million for 30 percent of the company; private investors, including the bank's top executives, pocketed $\$ 150$ million from the sale (Malkin 2008). The high valuation was not surprising since the bank was earning a return on equity of more than 40 percent. Another prominent example was SKS Microfinance in India, whose initial public offering in 2010 raised $\$ 350$ million; its founder Vikram Akula sold all his shares for $\$ 13$ million in a private sale (Bajaj 2011).

\section{The Decline of Microfinance}

All this euphoria surrounding microcredit has died down significantly in the last ten years. I was an early critic of microcredit, and argued in 2007 on conceptual grounds that Microfinance Misses its Mark (Karnani 2007). 
Other critics have gone further and argued that microfinance undermines sustainable development (Bateman 2011; see also Boje and Hillon 2017 in this journal issue). Much recent academic research based on empirical evidence, especially randomized control trial methodology, concludes that microcredit has no significant impact on poverty reduction (for example, Banerjee, Karlan and Zinman 2015). It might have some modest impact on consumption smoothing, risk management, and female empowerment; however, the primary objective and promise of microcredit is that it reduces poverty. Given the amount of financial and human resources that have been devoted to microcredit in the last three or four decades, lack of significant impact on reducing poverty is a strong criticism of microcredit. These resources could have been deployed more usefully in other poverty reducing interventions.

Why has microcredit not been effective at reducing poverty? A microcredit client is an entrepreneur in the literal sense: She raises the capital, manages the business, and takes home the earnings. But in the contemporary sense, 'entrepreneurs' are visionaries who convert new ideas into successful business models. Most people do not have the skills, vision, creativity, and persistence to be true entrepreneurs (Karnani 2007). Clients of microcredit are entrepreneurs by necessity, not out of choice. We should not romanticize the idea of the 'poor as entrepreneurs.' The International Labor Organization uses a more appropriate term: 'own account workers.'

There are other reasons as well why microcredit has not been effective at reducing poverty (Karnani 2011). The vast majority of microcredit borrowers use the loans for a nonbusiness purpose, such as repaying another loan, purchasing an appliance, or paying for some consumption activity. Borrowing to finance consumption certainly will not lead to higher income in the future. Microfinance interest rates are often in the range of 30 percent to 60 percent, and can sometimes be as high as 100 percent per year. If a borrower does not earn a return on investment greater than the interest rate, she will become poorer as a result of microcredit, not wealthier. Most businesses, and certainly most microenterprises, just are not that profitable compared to the interest rates. Most microenterprises are very simple businesses operating in an environment with low entry barriers, no competitive advantage, and hence low potential for profitability. The problem is compounded by microfinance organizations financing a constant stream of new entrants leading to market saturation and hyper-competition.

In the last decade there has been growing evidence that microcredit does not have a significant impact on reducing poverty. In spite of that, the 
global microfinance sector grew by 16 percent annually during the five years 2011-2015, and is expected to grow by 10-15 percent in 2016 (responsAbility 2016). In India, the microcredit sector has grown much faster, at the compounded annual growth rate of 44 percent during the years 2011-2015, and an impressive 64 percent growth in the fiscal year 2014-15 (Microfinance Institutions Network 2016).

What explains this incongruity between the rapid growth of the microcredit sector, especially in India, and the lack of its effectiveness in reducing poverty? It is likely that the growth is being driven by high profits of the sector, rather than achievement of some larger societal objective. In India, where for-profit microfinance organizations account for 95 percent of the microcredit sector, the microcredit industry earned an average return on equity of 10.5 percent in the year 2014-15; more than one-third of microcredit organizations earned a return on equity of above 15 percent. This is a very profitable industry indeed, but it is not helping reduce poverty.

\section{Poor as Producers}

The starting point for addressing the challenge of poverty is the simple and obvious observation that the primary problem of the poor is that they have a low income. The best way to alleviate poverty is to increase the income of the poor. In a modern market economy, income enables people to fulfill many of their basic needs. It is necessary to view the poor as producers, and emphasize buying from them (Karnani 2011). Many of the current approaches to poverty alleviation miss this simple point and hence are not as effective.

A fundamental fallacy of the BOP approach is that it views the poor primarily as consumers, as an attractive market for multinational firms. Even though the title of this article contains the word 'marketing,' the field of marketing cannot be the primary discipline driving poverty reduction, because it too views the poor primarily as consumers. Achrol and Kotler (2016) want to raise the "consumption capacity" of the poor, and view the poor primarily as consumers or customers: "the dominant theorem of marketing is customer orientation." Their framework for social marketing consists of seven elements: consumer psychology, geodemographics, segmentation, products and solutions, pricing, distribution, and promotion. This is quite parallel to marketing in general. The key difference is that in social marketing the focal organization is government or civil society that is driven by the goal of "achieving a socially desirable outcome ... profit is neither a primary nor a necessary condition". Social marketing does play a useful role in poverty reduction by helping the government to provide basic 
public services, as I will discuss below in the next section. To reduce poverty, we need to focus instead - and primarily - on increasing the productive capabilities of the poor.

\section{Employment}

Creating opportunities for steady employment at reasonable wages is the best way to take people out of poverty. The International Labor Organization (2007) states "nothing is more fundamental to poverty reduction than employment," and then goes further and argues vigorously for "decent employment" - work that offers a worker a good income, security, flexibility, protection and a voice at work. Employment is not only the key source of income, it also enhances other dimensions of well being including skills, physical abilities and self-respect. The International Finance Corporation (2013, p.4) argues, "jobs boost living standards, raise productivity, and foster social cohesion. Jobs also are the principal way out of poverty".

Increasing employment opportunities is, of course, a complex challenge and there is no magic solution. A whole variety of public policies and private strategies are needed to generate employment for the poor. Contemporary history clearly shows that it is the private sector that is the best engine of economic growth and job creation. For example, China has made the single largest contribution to global poverty reduction in the last three decades. Since the beginning of reforms in 1978, more than 250 million people have been lifted out of poverty in China. The private sector has been the fastest growing segment of the economy, growing at $20 \%$ per year for the last 25 years, more than double the economy's average. Since 1992, the private sector has created three quarters of all jobs created in China, according to the International Finance Corporation.

No country has significantly reduced poverty without experiencing rapid economic growth. There is much evidence linking neo-liberal economic policies to economic growth. For example, economic growth in India has picked up significantly after the neo-liberal reforms were started after the financial crisis in 1991. Sen and Dreze (2013, p.19) conclude that the "robustness of high growth in India is undoubtedly connected with the economic reforms of the 1990's".

Free market advocates often argue that the best antidote to poverty is economic growth - the so-called 'trickle down' effect (see, for example, Virmani 2006). It is assumed that economic growth will automatically lead to job creation that in turn will lead to poverty reduction. But, economic growth has had widely different impact on poverty reduction across countries. A one-percent increase in per capita GDP can reduce income 
poverty by as much as 4 percent or as little as 1 percent (Ravallion 2004). The link between economic growth and poverty reduction is mediated by job creation. Economic growth, and the associated neo-liberal economic policies, is a necessary, but not sufficient, condition for significant poverty reduction.

Even though the private sector is primarily responsible for job creation, governments, international organizations, and NGOs can and should facilitate this process. Generating employment requires regulatory policies that facilitate the creation and growth of private businesses. Other factors that influence business growth and job creation might include access to capital, financial system, pool of entrepreneurial talent, macroeconomic stability, infrastructure, and public services. To facilitate business growth, the government needs to emphasize providing infrastructure (such as electricity) and developing supporting institutions (such as capital markets). The International Finance Corporation (2013) report explores how the private sector generates jobs, what constraints limit job creation, and how these problems can be mitigated. Job creation is influenced by policies affecting macroeconomic and fiscal stability, investment climate and infrastructure, labor market regulations, education, and social safety net.

\section{Small and Medium Enterprises}

The non-government economy can be divided into three sectors: the informal sector (microenterprises), small and medium enterprises (SMEs), and large enterprises. World Bank research shows that the SME sector generates a higher fraction of GDP in high-income countries compared to low-income countries. As income increases, there is a marked shift from the informal to the SME sector. The economic structure in low-income countries is polarized with the informal and large enterprises playing a large role, with the SME sector being too small - the so-called 'missing middle.' The path to economic development is clearly associated with a growing role of the SME sector.

The International Labor Organization argues that SMEs are the major creators of employment opportunities and therefore hold an important key to employment and poverty reduction. SME expansion boosts employment more than large firms because SMEs are more labor intensive, less skill intensive, and less capital intensive - creating jobs better suited to the poor. This is also appropriate for developing countries with an abundance of labor and a relative shortage of capital. SMEs contribute to a more equitable income distribution because they tend to be more widely dispersed geographically than larger enterprises, thus helping 
to reduce economic disparities between urban and rural areas. Government policies that support the development of the SME sector play a critical role in poverty reduction. The private sector can help reduce poverty by creating employment opportunities suited to the poor in labor intensive, low skill sectors of the economy.

\section{Basic Public Services}

A major role of the government is to provide basic public services, such as education, public health, sanitation, security and infrastructure. Because these services are 'public goods' - there is a market failure - private firms cannot profitably provide these services. Even when the government privatizes such a service, it still plays a critical role by regulating or financing the service. Governments in virtually all countries accept the responsibility to provide basic public services, and make serious attempts to do so. To achieve a more egalitarian society, the government is responsible for providing additional services to the poor, services that it might not provide to more affluent people, such as basic health care and basic nutrition.

Providing access to basic public services is an essential part of poverty reduction. While having access to these services probably leads to increasing the productivity of the poor, it is important in and of itself. Amartya Sen (2009) says, "Social and economic factors such as basic education, elementary health care, and secure employment are important not only in their own right, but also for the role they can play in giving people opportunity to approach the world with courage and freedom". The most important role of the government in poverty reduction is providing basic public services to the poor. Yet the governments in most developing countries have failed dismally to provide these basic services. The poor bear a disproportionate share of the burden when the government fails in its responsibility to provide basic public services.

Whereas the rich often purchase these services from private enterprises, it is the middle class that is the main beneficiary of the public service expenditures. The poor have no or little access to these services, or get very low-quality public services, or pay very high prices for private services. For example, the rich go to world-class private hospitals and clinics. The middle class has access to reasonable public health facilities. While public health centers do exist to serve rural and poor areas, these centers are grossly underfunded and understaffed. Even worse, the staff may not be qualified, and are often absent. The rich hire private security guards. The middle class lives in reasonably well-policed neighborhoods. The poor have little protection from criminals and thugs. The rich have 
ample access to clean water; they purchase bottled drinking water and drill private tube wells. The middle class settles for piped water, even if only for a few hours a day, and often must boil or filter the water to make it potable. The poor often have no or little access to a clean public water supply, and often drink polluted water.

The burden of the failure of public services is also borne disproportionably by women, which exacerbates gender inequality. Lack of access to toilets poses a bigger problem for women because of anatomy, modesty, and susceptibility to attack. Women often lose much time to hauling buckets of water over long distances. They are more likely than men to need medical care; they are expected to care for sick family members, especially children. Girls also attend school less often, especially in poor families.

Just as there are many examples of market failure, there are many examples of government failure (Winston 2006). Government failure could be due to shortsighted, inflexible, and contradictory policies of government agencies. The government might lack the resources and competence to design and administer appropriate policies and to manage public services. If there is corruption in the government, the situation is even worse. A flawed political system might allow certain interest groups to influence government intervention to accrue economic rents at the expense of social welfare.

India provides an example of the failure of public services. The Indian economy is growing rapidly, the stock market is doing well, Indian companies are expanding abroad, and a large middle class is emerging. Economically, it is the best of times. Contrast this with the other side of India, characterized by persistent gender and caste inequality, and growing income inequality. According to the Rapid Survey on Children conducted by the Indian government in 2014, 39 percent of children are stunted and 35 percent of children are not fully immunized - although it is true that these measures have been improving over time. Forty-five percent of households lack adequate sanitation and practice open defecation. India is not alone in this failure of the state. About 844 million people in developing countries do not have access to clean drinking water, while 2.6 billion lack adequate sanitation. Nearly 1 billion people are illiterate (Karnani 2011).

There is no magic solution for these failures of the state, but we certainly should not accept them as inevitable. Giving a voice to the poor is vital to the development process. An intriguing possibility for empowering the poor is the recent rights-based approach to development in India and other countries. The government in India has passed into law 
rights to information, education, employment, and nutrition. Enacting a law, of course, does not automatically lead to the fulfillment of a societal need. But, it might serve to give a voice to the poor and make the government more accountable.

We need to get away from the stereotype that governments are always bureaucratic, wasteful, and corrupt. Several case studies demonstrate that government agencies and departments can, in fact, be flexible, creative, and entrepreneurial in addressing problems (Harris and Kinney 2003; Tepperman 2016). In the private sector, firms spend much resources and time learning from 'best practices.' The public sector needs to do the same. As an example, India is a large, diverse country, and parts of the Indian government have done well, much better than other parts of the system. Measured by the Multi-dimensional Poverty Index (developed by Oxford University Poverty and Human Development Initiative), the poor as a fraction of the population ranges from 79.3 percent in Bihar to 12.7 percent in Kerala (Kumar et al. 2015). There is room to learn 'best practices' here, and for inter-regional transfer of good governing practices.

\section{Social Marketing}

There are many examples of the poor not using public services targeted at them because the design and delivery of the services were not sufficiently sensitive to the social, cultural and psychological characteristics of the poor. This is where social marketing can play a very useful role, as Achrol and Kotler (2016) point out. For example, condoms clearly are useful for birth control and preventing sexually transmitted diseases. Adoption of condoms would have been much higher if governments had done a better job of social marketing.

Malaria used to kill nearly one million people every year, mostly in Africa (Karnani 2011). This is particularly tragic and reprehensible since malaria is preventable and treatable. Given the current state of technology, widespread use of long-lasting insecticide treated bed nets (ITNs), which repel and kill mosquitos, can significantly reduce malaria. Achrol and Kotler (2016) point out how some poor people were abusing or misusing the bed nets. Insights from social marketing - that take into account social, cultural and psychological factors - could usefully help with wider adoption and proper use of ITNs. Social marketing alone, however, is not enough; financial resources are often more critical. In 2007, the World Health Organization (WHO) put out a new position paper strongly advocating free distribution of ITNs. Arata Kochi, the head of WHO's antimalarial operations, estimated that a campaign costing about $\$ 10$ billion would be enough to bring malaria under control in most of Africa, 
and reduce the death rate to a few thousand per year from the current one million (The Economist 2008). Funding from international donors for malaria control has increased from $\$ 50$ million in 1997 to $\$ 1.7$ billion in 2009 to $\$ 2.9$ billion in 2015. In 2015, there were an estimated 429,000 malaria deaths worldwide, down from over a million per year, but still too high. According to WHO (2016), "in 2015, an estimated 53\% of the population at risk slept under ITNs compared to 30\% in 2010". More financial resources for such public services are needed.

India suffers from very poor human health outcomes (Rajagopal and Mohan 2015). India has among the world's highest rates for maternal mortality, infant mortality, and child malnutrition. The WHO recommends 3.5 hospital beds per 1,000 population, whereas in India there are only 0.7 hospital beds per 1,000 population. In spite of these poor health standards, India's government expenditure on health as a fraction of GDP is one of the lowest in the world: India, 1.2\%; China, 3\%; USA, 8.3\%; world average, $5.4 \%$. A combination of resources, good governance and social marketing can help in effectively designing and delivering basic public services.

\section{Conclusion}

Two essential elements for poverty reduction are creating jobs suited to the poor on a large scale and providing basic public service to the poor. Only the private sector can do the first: create jobs; but the government can play a useful facilitating role. Only the state can do the second: provide basic public services; and social marketing can play a useful role here. In a constructive vein, we need to find the appropriate policies and strategies that will enable the private and the public sectors to fulfill their responsibilities, and society should hold both the sectors accountable for their failures. 


\section{References}

Achrol, Ravi and Kotler, Philip (2016) "Marketing's Lost Frontier: The Poor," Markets, Globalization \& Development Review, 1 (1), Article 3.

Bajaj, Vikas (2011), "Amid scandal, Chairman of troubled lender will quit", The New York Times, November 23, 2011.

Banerjee, Abhijit, Karlan, Dean and Zinman, Jonathan (2015), "Six randomized evaluations of microcredit: Introduction and further steps", American Economic Journal: Applied Economics, 7 (1), 121.

Bateman, Milford (2011), Confronting Microfinance: Undermining Sustainable Development. Sterling VA: Kumarian Press.

Boje, David M., and Hillon, Yue Cai (2017), "The Fifth Epoch: SocioEconomic Approach to Sustainable Capitalism", Markets, Globalization \& Development Review, 2 (1), Article 2.

Gupta, Shruti (2013), "Making the case for harming the poor - a review of marketing tactics at the bottom of the pyramid", Journal of Applied Business and Economics, 14 (5), 30-40.

Harris, Michael, and Rhonda Kinney (2003), Innovation and Entrepreneurship in State and Local Governments. Lexington Books, Oxford.

Hart, Sturat L. (2015), 'Prologue. Defining the path towards a BoP 3.0' In Base of the Pyramid 3.0, Edited by Fernando Casado Caneque and Sturat L. Hart, Sheffield: Greenleaf Publishing Ltd.

International Finance Corporation (IFC) (2007), "The Next 4 Billion," Annual Report 2007, Washington D.C.

International Finance Corporation (2013), IFC Jobs Study. Assessing private sector contributions to job creation and poverty reduction, (accessed April, 17, 2017), [available at https://www.ifc.org/wps/wcm/connect/0fe6e2804e2c0a8f8d3bad7a9 dd66321/IFC FULL+JOB+STUDY+REPORT JAN2013 FINAL.pdf ?MOD=AJPERES].

International Labor Organization (2007), Global Employment Trends Brief, (accessed April, 14, 20017), [available at http://www.ilo.org/public/portugue/region/eurpro/lisbon/pdf/global tr ends 2007.pdf] 
Jaiswal, Anand Kumar (2008), "The fortune at the bottom or the middle of the pyramid", Innovations, Winter, 85-100.

Karnani, Aneel (2007), "Microfinance misses its mark", Stanford Social Innovation Review, Summer, 34-40.

Karnani, Aneel (2007), "The Mirage of Marketing to the Bottom of the Pyramid", California Management Review, 49 (4), 90-111.

Karnani, Aneel (2011), Fighting Poverty Together: Rethinking Strategies for Business, Governments, and Civil Society to Reduce Poverty. Palgrave Macmillan, New York.

Kolk Ans, Miguel Rivera-Santos, and Carlos Rufin (2014), "Reviewing a decade of research on the 'base/bottom of the pyramid' (BOP) concept", Business and Society, 53 (3), 338-477.

Kumar, Vinod, Surender Kumar, and Sonu (2015), "Multi-dimensional Poverty Index (MPI): A state wise study of India in SAARC countries", International Journal of Enhanced research in Educational Development, 3 (1), 14-21.

Malkin, Elisabeth (2008), "Microfinance's success sets off a debate in Mexico", The New York Times, April 5, 2008

M-CRIL Microfinance Review (2012), (accessed August 17, 2016), [Available at: http://www.mcril.com/BackEnd/ModulesFiles/Publication/M-CRIL-MicrofinanceReview-2012-MFIs-in-a-Regulated-Environment.pdf]

Micro Finance Institutions Network (2016), The MicroScape FY 2014-15. (accessed August 18, 2016), [Available at: http://mfinindia.org/wpcontent/uploads/2016/01/Microscape\%20FY\%2014$15 \quad 07$ 7th\%20Jan\%202016 for\%20releasev0.1.pdf]

Monitor Group (2009), Emerging Markets, Emerging Models. Cambridge, MA, (accessed February 28, 2017), [Available at: http://communitywealth.org/content/emerging-markets-emerging-models-marketbased-solutions-challenges-global-poverty]

Prahalad, C.K. (2005), Fortune at the Bottom of the Pyramid: Eradicating Poverty through Profits. Wharton School Publishing.

Prahalad, C.K., and A. Hammond (2002), "Serving the world's poor profitably", Harvard Business Review.

Prahalad, C.K., and S.L. Hart (2002), "The fortune at the bottom of the pyramid", Strategy + Business. 
Rajagopal, Divya, and Rohini Mohan (2015), "India's disproportionately tiny health budget: a national security concern", The Economic Times, October 31, 2015.

Ravallion, Martin (2004), "Pro-Poor Growth: A Primer", World Bank, Washington D.C.

responsAbility Investments AG. Microfinance Market Outlook. 2016, (accessed August 18, 2016), [Available at: http://www.responsability.com/funding/data/docs/en/17813/Microfin ance-Outlook-2016-EN.pdf]

Yurdakul, Dicle, Atik, Deniz and Dholakia, Nikhilesh (2017), "Redefining the bottom of the pyramid from a marketing perspective", Marketing Theory, forthcoming, Doi: 10.1177/1470593117704265.

Sen, Amartya (2000), Development as Freedom. Anchor Books, New York.

Sen, Amartya (2009), The Idea of Justice. The Belknap Press of Harvard University Press.

Sen, Amartya, and Jean Dreze (2013), An Uncertain Glory. Princeton University Press, Princeton.

Tepperman, Jonathan (2016), The Fix. New York: The Duggan Books.

The Economist (2008), "Net benefits", The Economist, January 31, 2008.

United Nations (2015), "Millennium Development Goals and Beyond 2015," report, (accessed April 17, 2017), [available at http://www.un.org/millenniumgoals/pdf/Goal_1_fs.pdf].

Virmani, A. (2006), "Poverty and hunger in India: what is needed to eliminate them", Working Paper No. 1/2006-PC, Planning Commission, The Government of India.

Warnholz, Jean-Louis (2007), "Poverty reduction for profit? a critical examination of business opportunities at the bottom of the pyramid", Working Paper 160, Queen Elizabeth House, University of Oxford.

Winston, Clifford (2006), Government Failure versus Market Failure. Brookings Institution Press, Washington, D.C.

World Health Organisation (2016), World Malaria Report 2016. World Health Organisation. 
Yunus, Muhammad (1998), "Poverty alleviation: is economics any help? Lessons from the Grameen Bank experience", Journal of International Affairs, 52 (1), 47-65. 